MIMESIS
Und
Universitas
Ahmad Dahlan

\title{
KONSTRUKSI IDEOLOGI PEMERINTAH ATAS PRAKTIK RADIAKLISME, ANARKISME DAN INTOLERAN OLEH ORMAS: SEBUAH PENDEKATAN TEKSTUAL DAN KRITIS
}

\author{
Nadia Khumairo Ma'shumah \\ Email : nadia.khumairo@gmail.ugm.ac.id,_Magister Linguistik, Fakultas Ilmu Budaya,_Universitas Gadjah \\ Mada, Jl. Sosio Humaniora, Bulaksumur, Yogyakarta
}

\section{Article history}

Received

Revised

Accepted

Keywords

Radicalism,

Anarchism,

Intolerance,

Ideology,

Critical Discourse Analysis,

Systemic Functional Linguistics
The conflict between FPI and the government forms a long story line. As a party that has legitimacy, the government has full access and power in the form of authority in determining policies, implementing law enforcement efforts and regulating access to the mass media to stem and withdraw the legality of community movements. This study seeks to identify and examine ideological construction through the production of discourse. This is echoed and rolled out by the government and the National Police in framing public perceptions of FPI. This research is a qualitative descriptive study combining the LSF theory as a conceptual framework and $A W K$ as an analytical framework. The results of the research through analysis at the description stage, discursive practice of discourse and social practice show that the ideological construction in the discourse of 7 government restrictions on FPI on December 30, 2020 and the Chief of Police's Declaration on the Prohibition of FPI Activities on January 1, 2021 are reflected in the government's efforts to legitimize the situation by showing that there are the inequality of power that is to be perpetuated and maintained through the existing rules and through the choices of words represented in the two discourses.

This is an open access article under the CC-BY-SA license.

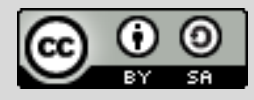

\section{Artikel histori}

Dikirim

Diperbaiki

Diterima

Kata kunci

Radikalisme,

Anarkisme,

Intoleran,

Ideologi,

Analisis Wacana Kritis,

Linguistik Sistemik Fungsional
Konflik antara FPI dan pemerintah membentuk alur cerita yang panjang. Sebagai pihak yang memiliki legitimasi, pemerintah memiliki akses serta kekuasaan penuh dalam bentuk otoritas dalam menentukan kebijakan, melaksanakan upaya penegakan hukum serta mengatur akses terhadap media massa untuk membendung serta menarik legalitas pergerakan masyarakat. Penelitian ini berupaya untuk mengidentifikasi serta mengkaji upaya konstruksi ideologi melalui produksi wacana yang didengungkan serta digulirkan pemerintah dan Kapolri dalam membingkai persepsi publik terhadap FPI. Penelitian ini merupakan penelitian deskriptif kualitatif memadukan teori LSF sebagai kerangka kerja konseptual dan AWK sebagai kerangka kerja analitis. Hasil penelitian melalui analisis pada tahap deskripsi, praktik diskursif wacana dan praktik sosial menunjukkan bahwa konstruksi ideologi dalam wacana 7 larangan pemerintah terhadap FPI pada 30 Desember 2020 serta Maklumat Kapolri tentang Larangan Kegiatan FPI pada 1 Januari 2021 tercermin dalam bentuk upaya pemerintah melegitimasi keadaan dengan menunjukkan adanya ketidaksetaraan kuasa yang hendak dilanggengkan dan dipertahankan melalui aturan yang ada serta melalui pilihan-pilihan kata yang direpresentasikan dalam kedua wacana.

This is an open access article under the CC-BY-SA license. 


\section{PENDAHULUAN}

Dewasa ini, pemerintah dihadapkan pada kondisi munculnya sikap intoleran serta ancaman radikalisme dan anarkisme dalam praktik kegiatan organisasi masyarakat di Indonesia. Sikap radikalisme, anarkisme dan intoleran secara masif memicu adanya konflik di berbagai daerah. Penelitian ini menitik beratkan kasus Front Pembela Islam (FPI) sebagai sebuah organisasi massa Islam yang menganut paham radikal mengutamakan solidaritas emosional daripada mekanisme formal organisasi. Konflik antara FPI dan pemerintah membentuk alur cerita yang panjang dipicu oleh adanya corak konfrontatif dan radikal terhadap sistem sosial-politik pemerintah. Sistem sosial-politik pemerintah dipahami sebagai sistem yang sekuler atau disebut sebagai Jahilia Modern. Dalam praktiknya, FPI menuntut perubahan sistem pemerintahan menjadi sistem berbasis syariat Islam (Nizam Islam). Beragam bentuk aksi dan gerakan yang ada, menimbulkan pro dan kontra. Masyarakat yang tidak setuju menuntut pemerintah untuk membubarkan FPI karena dianggap sebagai gerakan yang meresahkan masyarakat, sedangkan spekulasi melalui perspektif politik menyatakan bahwa gerakan separatis FPI merupakan upaya untuk menggulingkan pemerintahan saat ini.

Pada 30 Desember 2020, pemerintah melalui Wakil Menteri Hukum dan HAM, membacakan serta memproklamirkan 7 larangan pemerintah untuk FPI yang menandai pembubaran serta pencabutan legal standing FPI di Indonesia. Sejalan dengan pemerintah, pada tanggal 1 Januari 2021, Kapolri menerbitkan Maklumat tentang Larangan Kegiatan FPI serta penggunaan simbol dan atribut FPI di wilayah NKRI. Dalam hal ini, pemerintah menggunakan istilah radikalisme, anarkisme serta intoleran untuk menggambarkan aksi-aksi destruktif yang dilakukan FPI mengacu pada aksi-aksi yang dilakukan FPI selama ini. Selain pemerintah, wacana media massa turut berpengaruh serta dikonstruksi sedemikian rupa sehingga memunculkan praanggapan FPI sebagai pihak yang direpresi serta dibatasi ruang pergerakannya dan pendapatnya di media melalui restriksi larangan. Represi media dan pemerintah dalam hal ini menyebabkan ketimpangan pertarungan wacana dalam membentuk persepsi publik antara kuasa pemerintah melawan FPI sebagai pihak yang direpresi. Dikotomi pemerintah dan media menunjukkan bahwa bahasa telah menjadi media perantara dalam pelaksanaan kuasa melalui ideologi. Bahasa juga menyumbang proses dominasi terhadap orang lain oleh pihak lain (Fairclough, 1995:12).

Berkaitan dengan latar belakang yang ada, penelitian ini berupaya untuk mengidentifikasi serta mengkaji upaya konstruksi ideologi melalui produksi wacana yang didengungkan serta digulirkan pemerintah dan Kapolri dalam membingkai persepsi publik terhadap FPI sebagai pihak yang melakukan praktik radikalisme, anarkisme dan intoleran. Sebagai pihak yang memiliki legitimasi, pemerintah serta Kapolri memiliki akses serta kekuasaan penuh dalam bentuk otoritas dalam menentukan kebijakan, melaksanakan upaya penegakan hukum serta mengatur akses terhadap media massa untuk membendung serta menarik legalitas pergerakan masyarakat. Sedangkan FPI diposisikan sebagai pihak yang dikunci ruang geraknya oleh pemerintah.

Penelitian ini mengadopsi teori Lingustik Sistemik Fungsional (LSF) yang dikemukakan oleh Halliday (2004) serta Halliday dan Matthiessen (2014) sebagai sebuah 


MIMESIS
Und. 2. No. 1, Januari 2021
Universitas
Ahmad Dahlan

pendekatan yang menyelidiki bagaimana bahasa berfungsi untuk membentuk dan merekonstruksi makna dalam konteks situasi. Pemilihan teori Lingustik Sistemik Fungsional (LSF) sebagai pendekatan analisis wacana dilandaskan pada pemikiran bahwa pendekatan ini terbukti mampu menjawab berbagai persoalan kebahasaan baik secara mikro maupun makro. LSF sebagai pendekatan tekstual dalam penelitian ini digunakan sebagai pisau bedah yang kuat (powerful tool) melalui analisis terhadap tiga strata Metafungsi Halliday yang diungkapkan melalui struktur transitivitas (proses, partisipan dan sirkumstan), hubungan mood-residue, serta hubungan tema-rema sebagai struktur tematik. Analisis metafungsi menggunakan pendekatan LSF digunakan untuk mengungkap representasi pengalaman (metafungsi ideational atau experiential), pertukaran makna (metafungsi interpersonal) serta pesan yang terkandung dalam wacana yang dibangun (matafungsi tekstual).

Namun, fenomena sosial di masyarakat terlalu komplek jika hanya dikaji secara tradisional menggunakan pendekatan tunggal. Dalam rangka mencapai kedalaman analisis, penelitian ini mengkombinasikan teori Linguistik Sistemik Fungsional Halliday (2004) sebagai pendekatan tekstual serta pendekatan Analisis Wacana Kritis Fairclough (1995) sebagai pendekatan kritis membentuk pendekatan interdisipliner untuk mengungkap ideologi pemerintah dalam menyikapi serta mengatasi praktik radikalisme, anarkisme dan intoleran oleh organisasi masyarakat (dalam hal ini FPI) dalam konstruksi struktur bahasa dalam wacana strategis. Dalam memandang kondisi sosial, AWK memusatkan perhatian pada bagaimana situasi-situasi sosial direproduksi, dilegitimasi serta diaplikasikan melalui sebuah wacana (Van Dijk, 2004; Silaswati, 2019).

Dalam hal ini, Van Dijk, Fairclough dan Wodak dalam Paltridge (2012: 187) merumuskan karakteristik Analisis Wacana Kritis berupa (1) Isu-isu sosial dan politik dikonstruksi dan direfleksikan dalam wacana; (2) Relasi kuasa dinegosiasikan dan dimainkan melalui wacana; (3) Wacana merefleksikan dan memproduksi relasi sosial: (4) Ideologi diproduksi dan direfleksikan melalui penggunaan wacana. Mengacu pada Analisis Wacana Kritis (AWK) menggunakan pendekatan Fairclough (1995), Jorgensen dan Phillips (2002) menyebut pendekatan Fairclough sebagai analisis diskursus yang berorientasi pada teks dengan menyatukan tiga tradisi, meliputi 1) Analisis tekstual dalam bidang linguistik (termasuk teori Linguistik Sistemik Fungsional (LSF) Halliday); (2) Analisis meso atau makro-sosiologis dari praktik sosial; (3) tradisi interpretatif mikro-sosiologis yang membentuk keterkaitan antara situasi, institusi dan praktik sosial. Dengan menyatukan ketiga tradisi, Fairclough membangun anggapan bahwa analisis teks berbasis linguistik tidak cukup digunakan karena tidak dapat mengungkap lebih jauh kondisi sosial yang melatarbelakangi produksi teks. Fairclough juga berpendapat bahwa analisis teks pada dasarnya merepresentasikan pemikiran, kepentingan serta ideologi yang dilekatkan pada teks (Wodak dan Meyer, 2010: 8). Sesuai dengan tujuan dari penelitian AWK, penelitian ini pada akhirnya tidak saja sekadar menganalisis wacana dari segi teks melainkan pula konteks kekuatan sosial yang muncul diantara para patisipan yang terlibat (Rumata dan Elfrida, 2019: 96). 


MIMESIS
Und. 2. No. 1, Januari 2021
Universitas
Ahmad Dahlan

\section{METODE}

Penelitian ini merupakan penelitian deskriptif kualitatif yang berfokus pada deskripsi dan interpretasi terhadap fenomena yang menjadi objek kajian dalam penelitian (Anggito dan Setiawan, 2018). Penelitian ini memaparkan serta menjabarkan struktur wacana melalui analisis Linguistik Sistemik Fungsional (LSF) terhadap teks 7 larangan pemerintah terhadap FPI pada 30 Desember 2020 yang dikutip dari portal berita KompasTV dan Maklumat Kapolri tentang Larangan Kegiatan FPI pada 1 Januari 2021 yang dikutip dari portal berita CNN Indonesia dengan pendekatan tiga metafungsi meliputi metafungsi Ideational, Interpersonal, dan Tekstual. Struktur wacana dianalisis guna mengidentifikasi aspek-aspek yang terdapat dalam wacana (Suswandi, 2020: 24). Sedangkan Analisis Wacana Kritis (AWK) digunakan sebagai pendekatan untuk mengidentifikasi usaha dan ideologi pemerintah dalam membingkai persepsi masyarakat terhadap FPI. Dalam hal ini, LSF berfungsi sebagai kerangka kerja konseptual, sedangkan AWK berfungsi sebagai kerangka kerja analitis.

Dalam menggabungkan antara LSF dan AWK, penelitian ini dilakukan dengan metode simak dan catat dengan menempatkan peneliti sebagai instrument primer. Bagian dari naskah pidato dipecah menjadi paragraf, kalimat, hingga pada akhirnya sampai pada tataran klausa serta dikaji melalui tiga tahapan Analisis Wacana Kritis Fairclough (1995:198), meliputi tahapan deskripsi, interpretasi dan eksplanasi. Tahapan Analisis Wacana Kritis Fairclough (1995:198) diilustrasikan sebagai berikut.

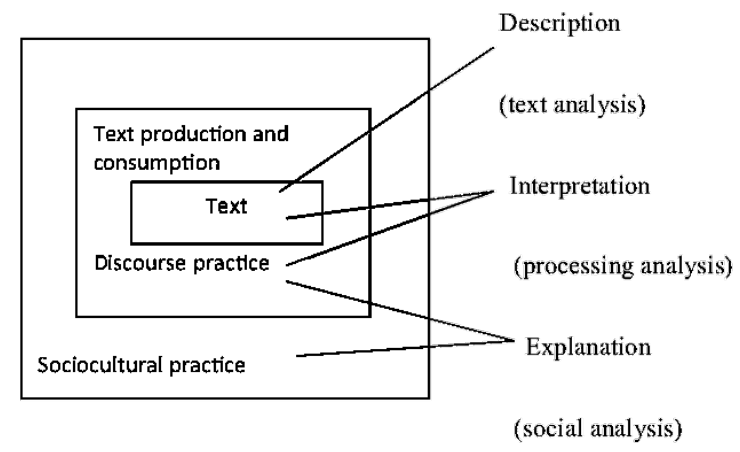

Gambar 1. Dimensi Analisis Wacana Kritis Fairclough (1995:198)

\section{PEMBAHASAN}

\section{Deskripsi Teks melalui Sistem Transitivitas sebagai Manifestasi dari Makna Ideational (Klausa sebagai Representasi Pengalaman)}

Fungsi Ideational dari sebuah klausa sebagai representasi dari pengalaman adalah untuk melambangkan proses seperti tindakan, peristiwa, kesadaran dan hubungan (Halliday dan Matthiessen, 2014: 30). Analisis transitivitas terhadap teks atau wacana 7 larangan pemerintah terhadap FPI pada 30 Desember 2020 dan Maklumat Kapolri tentang Larangan Kegiatan FPI pada 1 Januari 2021 menunjukkan bahwa proses verbal mendominasi keseluruhan proses (meliputi proses material, mental dan verbal) dalam 18 klausa yang menyusun teks 7 larangan pemerintah terhadap FPI pada 30 Desember 2020. Sedangkan proses material mendominasi 


MIMESIS
Und. 2. No. 1, Januari 2021
Universitas
Ahmad Dahlan

keseluruhan proses (meliputi proses Material, Mental, Verbal, Relational Dan Existential) dalam 11 klausa yang menyusun teks Maklumat Kapolri tentang Larangan Kegiatan FPI pada 1 Januari 2021.

Proses Material

Dalam fungsi ideational atau experiential, proses material merupakan proses kerja yang menunjukkan perbuatan (process of doing) atau peristiwa/kejadian (process of happening) (Halliday dan Matthiessen, 2014). Proses Material direalisasikan melalui verba yang menujukkan aktivitas fisik (Wiratno, 2018:92). Proses material diikuti oleh partisipan yang melakukan sesuatu yang disebut Actor, penerima yang disebut Recipient dan partisipan lain yang dituju oleh proses yang disebut Goal (Martin, dkk., 1997:103-5).

(1) FPI (Actor) masih terus melakukan (Proses Material) kegiatan (Goal)

(2) (Kegiatan FPI) (Actor) bertentangan (Proses Material) dengan hukum (Goal).

(3) (Kapolri) (Actor) menghentikan (Proses Material) kegiatan Front Pembela Islam (Goal).

(4) (Masyarakat) (Actor) tidak mengakses, mengunggah, dan menyebarluaskan (Proses Material) konten terkait FPI (Goal).

(5) Anggota Polri (Actor) wajib melakukan (Proses Material) tindakan yang diperlukan...(Goal).

Kutipan (1), (2), (3), (4) dan (5) menunjukkan bahwa proses material yang ditemukan dalam kedua teks didominasi oleh konstruksi dalam bentuk aktif melalui verba transitif dalam struktur || S | F / P | A ||. Penempatan FPI sebagai Actor mengindikasikan bahwa FPI adalah pihak yang direpresi, dibatasi serta dihentikan pergerakannya di Indonesia berkaitan dengan praktik radikalisme, anarkisme dan intoleran yang gencar dilakukan. Penempatan masyarakat sebagai Actor menunjukkan adanya pihak yang didominasi guna membendung akses dan persebaran FPI pasca diterbitkannya larangan serta maklumat. Sedangan penempatan Kapolri dan anggota Polri sebagai Actor menunjukkan adanya usaha menunjukkan dominasi dan kuasa (power) dari Kapolri dan Polri sebagai benteng terkokoh dalam menangkal dan menghentikan praktik radikalisme, anarkisme dan intoleran yang dilakukan oleh FPI dalam usaha menjaga persatuan dan kesatuan NKRI.

Analisis komprehensif terhadap proses material kedua teks menunjukkan adanya pola yang sama, dimana pada teks 7 larangan pemerintah terhadap FPI pada 30 Desember 2020 otoritas dan kuasa berada di tangan pemerintah, sebagai bentuk perintah kepada aparat penegak hukum dan masyarakat guna menghentikan praktik radikalisme, anarkisme dan intoleran yang dilakukan oleh FPI. Sedangkan, pada teks Maklumat Kapolri tentang Larangan Kegiatan FPI pada 1 Januari 2021 otoritas dan kuasa berada di tangan Kapolri dalam membentuk persepsi (framing) masyarakat bahwa aktivitas FPI memang harus dan pantas untuk dihentikan.

Proses Verbal

Proses verbal merupakan realisasi atau representasi linguistik dari gagasan atau ide yang dimiliki oleh manusia, meliputi modus menyatakan, menanyakan, menawarkan, memerintahkan, memberitahukan, mengatakan (Wiratno, 2018: 101). Pada proses verbal terdapat partisipan yang disebut sebagai pewarta (Sayer), penerima (Receiver) dan diwartakan (Verbiage).

(6) (Pemerintah) (Sayer) melarang (Proses Verbal) dilakukannya kegiatan FPI serta penggunaan simbol dan atribut FPI dalam wilayah hukum NKRI (Verbiage).

(7) (Pemerintah) (Sayer) meminta (Proses Verbal) kepada masyarakat... (Receiver). 


MIMESIS
Und. 2. No. 1, Januari 2021
Universitas
Ahmad Dahlan

(8) Kapolri (Sayer) melarang (Proses Verbal) kegiatan, penggunaan simbol dan atribut...(Verbiage).

Kutipan (7) merupakan contoh proses verbal dengan menunjukkan hubungan antara Sayer, Proses Verbal, Receiver. Proses dinyatakan dengan verba meminta. Sedangkan kata pemerintah berkedudukan atau berfungsi sebagai Sayer, kepada masyarakat berkedudukan atau berfungsi sebagai Reciever. Sedangkan kutipan (6) dan (8) merupakan contoh proses verbal yang menunjukkan hubungan antara Sayer, Proses Verbal dan Verbiage.

Analisis terhadap ketiga kutipan menunjukkan adanya dominasi dari Pemerintah dan Kapolri selaku pemangku kepentingan dengan menunjukkan legitimasi serta membentuk citra negatif terhadap FPI sebagai pihak yang harus dihindari dan dicekal ruang geraknya.

Proses Relational

Proses Relational adalah proses of being yang menunjukkan hubungan intensitas dan hubungan perluasan makna (Wiratno, 2018:96). Proses relasional dalam hubungan intensitas dibagi menjadi dua subjenis, yaitu proses relasional atributif dan proses relasional identifikatif. Proses relasional atributif diikuti partisipan penyandang (Carrier) yang disertai sandangan (Attribute). Sementara itu, proses relasional identifikatif mempunyai partisipan Token (diidentifikasi) dan Value atau nilai (pengidentifikasi). Token dan Value memiliki kedudukan yang sama sehingga posisi keduanya dapat dibalik (Wiratno, 2018:97).

(9) Kegiatan (FPI) (Carrier) mengganggu (Proses Relational- Attributive) ketentraman dan ketertiban umum (Attribute).

(10) ... nasib FPI yang di bawah pimpinan Rizieq Shihab (Carrier) tidak memiliki (Proses Relational- Attributive) legal standing (Attribute).

Kutipan (9) dan (10) menunjukkan proses Relasional Atributif yang diindikasi dengan menggunakan verba mengganggu dan tidak memiliki serta memposisikan FPI sebagai Carrier. Proses Relasional Attributive dalam teks sengaja digunakan oleh pemerintah dalam teks 7 larangan pemerintah terhadap FPI pada 30 Desember 2020 untuk meletakkan Atribute, mendefinisikan ideologi penutur, serta juga menghubungkan fakta melalui representasi atribut yang menekankan bahwa kegiatan FPI telah mengganggu ketentraman dan ketertiban umum terkait praktik radikalisme, anarkisme dan intoleran. Sedangkan kalimat "nasib FPI yang di bawah pimpinan Rizieq Shihab tidak memiliki legal standing” mengukuhkan bahwa FPI resmi dilarang kegiatannya setelah 7 larangan pemerintah terhadap FPI pada 30 Desember 2020 melalui legitimasi pemerintah.

(11) FPI (Token) adalah (Proses Relational- Identifying) organisasi yang tidak terdaftar sebagai organisasi kemasyarakatan sebagaimana diatur dalam peraturan undangundang (Value).

Kutipan (11) menunjukkan proses relasional identifikatif dengan menunjukkan hubungan Token dan Value sebagai hubungan saling berpengaruh dan saling menggantikan. Hubungan antara Token dan Value mengukuhkan bahwa keberadaan FPI selama ini dianggap ilegal dan tidak sah secara hukum di Kementerian Dalam Negeri sejak tidak diperpanjangnya izin mendirikan ormas sejak Juni 2019. 


UADESIS
Universitas
Ahmad Dahlan

Proses Eksistential

Proses Eksistensial menunjukkan keberadaan sesuatu (ada, terdapat, muncul) yang ditandai dengan hadirnya partisipan tunggal yang disebut eksisten yang mengikuti proses (Wiratno, 2018:106).

(12) Mulai berlakunya (Proses Eksistensial) keputusan ini...(Eksisten).

(13) Dengan berlakunya (Proses Eksistensial) keputusan ini ...(Eksisten).

Kutipan (12) dan (13) menunjukkan proses eksistensial yang dimarkahi dengan penggunaan kata mulai berlaku dan dengan adanya. Sementara, peristiwa yang hadir dalam klausa (12) dan (15) adalah keputusan ini yang merujuk pada 7 larangan pemerintah terhadap FPI pada 30 Desember 2020 yang berfungsi untuk mengukuhkan larangan yang tidak dapat diganggu gugat.

Proses Mental

Proses Mental adalah process of sensing yang mengindikasikan adanya proses yang menerangkan persepsi (melihat, mendengar, merasa), afeksi (suka, takut, khawatir), kognisi (berpikir, mengerti, menganggap), keinginan (menginginkan, berharap), dan kehendak (dibutuhkan) (Wiratno, 2018:94). Proses mental diiikuti oleh partisipan pengindera (Senser) dan fenomena (Phenomenon).

(14) (Masyarakat) (Senser) agar tidak terpengaruh (Proses Mental) dalam kegiatan, penggunaan simbol dan atribut FPI (Phenomenon).

(15) (Masyarakat) (Senser) mengedepankan (Proses Mental) Satpol PP dengan didukung sepenuhnya oleh TNI-Polri (Phenomenon).

Kutipan (14) dan (15) menunjukkan proses mental dengan memposisikan masyarakat sebagai senser atau pengindera. Dalam hal ini, pemerintah dan Kapolri memandang bahwa masyarakat merupakan pihak yang paling mudah terpengaruh dengan berbagai macam aksi yang mengatasnamakan keberpihakan kepada masyarakat. Proses mental dalam kutipan teks ini mengindikasikan adanya usaha pemerintah dan Kapolri dalam memutus praktik radikalisme, anarkisme dan intoleran menurut versi pemerintah.

Secara umum, terdapat perbedaan mendasar pada kedua teks yang diajukan pemerintah dan Kapolri terkait dengan larangan untuk FPI jika dipandang melalui struktur transitivitas. Teks 7 larangan pemerintah terhadap FPI pada 30 Desember 2020 memiliki otoritas yang penuh dengan memberikan perintah kepada seluruh aspek yang terkait dan berpotensi memiliki keterkaitan. Sedangkan, Maklumat Kapolri tentang Larangan Kegiatan FPI pada 1 Januari 2021, Kapolri berada di bawah otoritas dan kuasa pemerintah.

Elemen Sirkumstansi dalam Sistem Transitivitas

Elemen Sirkumstansi digunakan sebagai keterangan tambahan yang bersifat opsional dalam klausa yang mengikuti proses dan partisipan. Berdasarkan analisis yang telah dilakukan terhadap Maklumat Kapolri tentang Larangan Kegiatan FPI pada 1 Januari 2021, elemen sirkumstansi muncul dalam bentuk cara dan tujuan guna memperjelas isi larangan dan maklumat. Sedangkan pada teks 7 larangan pemerintah terhadap FPI pada 30 Desember 2020 elemen sirkumstansi didominasi dalam bentuk waktu dan kondisi. Hal ini berkaitan dengan relevansi larangan dihubungkan dengan konteks permasalahan yang dihadapi.

\footnotetext{
Sistem Modus dan Modalitas sebagai Manifestasi dari Makna Interpersonal (Klausa sebagai Pertukaran Makna)

Dalam Fungsi Interpersonal, bahasa digunakan untuk mengungkapkan realitas sosial dan berkenaan dengan interaksi antara penulis dan pembaca (Eggins, 2004:11). Dalam susunan
} 


MIMESIS
Undiversitas
Ahmad Dahlan
VOL. No. 1, Januari 2021

klausa, sistem modus dan Modalitas sering digunakan untuk mengekspresikan fungsi Interpersonal. Dalam hal ini, sistem modus menunjukkan peran yang dipilih pembicara dalam situasi bicara serta peran yang pembicara berikan kepada penerima atau pendengar (Halliday dan Matthiessen, 2014:143). Sedangkan, modalitas secara objektif mengungkapkan penilaian pembicara terhadap topik, menunjukkan hubungan peran sosial, skala formalitas dan hubungan kekuasaan (Chaer, 1994: 262). Alwi (1992: 4) mengemukakan bahwa perbedaan dengan modus, yang sama-sama merupakan pengungkap sikap yang diambil oleh penutur, terletak pada kategorinya. Modus merupakan kategori gramatikal, sedangkan modalitas merupakan kategori semantis.

Dalam teks 7 larangan pemerintah terhadap FPI pada 30 Desember 2020, sebanyak 8 klausa dinyatakan dalam modus deklaratif dan 6 klausa dinyatakan dalam modus imperatif berupa perintah. Sedangkan dalam Maklumat Kapolri tentang Larangan Kegiatan FPI pada 1 Januari 2021, sebanyak 8 klausa dinyatakan dalam modus imperatif dan sebanyak 1 klausa dinyatakan dengan modus deklaratif. Penggunaan modus deklaratif dalam kedua teks tersebut dimana kegiatan FPI merupakan kegiatan yang meresahkan serta syarat akan praktik radikalisme, anarkisme dan intoleran, menempatkan FPI sebagai satu-satunya pihak yang disalahkan atas berbagai kekacauan, tekanan, serta tuntutan yang dilayangkan massa kepada pemerintah. Sedangkan penggunaan modus imperatif menempatkan Kapolri serta pemerintah sebagai pembicara serta pemilik otoritas dan kuasa yang mengambil peran sebagai pemberi perintah dan menempatkan penerima atau pendengar (dalam hal ini FPI dan masyarakat) dalam peran yang diharapkan untuk mematuhi perintah.

Ditinjau dari penggunaan modalitas, kedua teks didominasi dengan penggunaan modalitas deontik sebanyak 4 kali kemunculan dalam bentuk larangan dan perintah dalam teks 7 larangan pemerintah terhadap FPI pada 30 Desember 2020 yang diungkapkan melalui kata melarang, akan menghentikan, harus melaporkan, agar melakukan koordinasi, diikuti dengan modalitas intensional dengan frekuensi kemunculan sebanyak 1 kali yang diungkapkan dengan kata meminta. Sedangkan pada teks Maklumat Kapolri tentang Larangan Kegiatan FPI pada 1 Januari 2021 modalitas deontik muncul sebanyak 8 kali dalam bentuk perintah dan larangan menggunakan kata melarang, tidak terlibat, menghentikan, tidak mengakses, mengunggah, dan menyebarluaskan, tidak melakukan, segera melaporkan, mengedepankan, serta wajib melakukan.

\section{Konstruksi Tema dan Rema sebagai Manifestasi dari Makna Tekstual (Klausa sebagai Pesan)}

Fungsi Tekstual bahasa pada prinsipnya adalah fungsi bahasa (fungsi yang dilakukan pemakai bahasa) untuk merangkai dan menautkan pesan yang disampaikan sehingga pesan membentuk kesatuan yang padu. Fungsi Tekstual membentuk konstruksi tema dan rema yang menentukan apa yang ingin disampaikan oleh pemakai bahasa. Fungsi Tekstual memenuhi persyaratan bahwa bahasa harus relevan secara operasional serta memiliki tekstur dalam konteks situasi (Wiratno dan Santoso, 2011). Tema didefinisikan sebagai titik awal pesan (the starting point of the message) di dalam klausa. Dalam dinamika pemakaian bahasa, jika tema telah terwujud, maka bagian dari klausa selanjutnya disebut rema yang didefinisikan sebagai sisa pesan (the rest of the message). Berkaitan dengan hal ini, Eggins (2004: 299) mengemukakan bahwa tema adalah elemen yang muncul pertama dalam klausa, sedangkan rema merupakan bagian klausa yang dikembangkan dari tema. Sebagai titik awal pesan, tema direalisasikan berdasarkan posisi dan penanda. Dengan kata lain, tema dapat dialokasikan berdasarkan urutan (order) dan pemarkah (marker). Pengertian tema sebagai titik awal atau 


MIMESIS
Und. 2. No. 1, Januari 2021
Universitas
Ahmad Dahlan

titik mula pesan berimplikasi pada pengembangan tema-rema menjadi teks yang lebih besar atau wacana (Saragih, 2007).

Berdasarkan analisis terhadap teks 7 larangan pemerintah terhadap FPI pada 30 Desember 2020, teks membentuk pola pengembangan berimpitan atau sungsang dimana proses pengembangan teks bermula dari struktur tema-rema dari satu klausa sebagai klausa pertama yang kemudian berkait. Rema klausa pertama menjadi dasar dari tema klausa kedua dan seterusnya yang dicontohkan dalam kutipan berikut.

(16) FPI (Tema) adalah organisasi yang tidak terdaftar sebagai organisasi kemasyarakatan sebagaimana diatur dalam peraturan undang-undang sehingga secara de jure telah bubar sebagai organisasi kemasyarakatan (Rema).

(17) FPI sebagai organisasi kemasyarakatan yang secara de jure telah bubar (Tema) masih terus melakukan kegiatan (Rema).

(18) Kegiatan FPI (Tema) mengganggu ketentraman dan ketertiban umum (Rema).

Dalam kutipan (16), (17) dan (18) ditampilkan wacana yang dikembangkan dengan pola sungsang. Secara spesifik dapat diidentifikasi bahwa tema pada klausa pertama adalah FPI dan rema adalah adalah organisasi yang tidak terdaftar sebagai organisasi kemasyarakatan sebagaimana diatur dalam peraturan undang-undang sehingga secara de jure telah bubar sebagai organisasi kemasyarakatan. Dari rema klausa pertama dikonstruksi tema klausa "kedua, FPI sebagai organisasi kemasyarakatan yang secara de jure telah bubar" dengan remanya "masih terus melakukan kegiatan". Dari rema kegiatan diturunkan tema klausa ketiga dengan menggunakan rema "mengganggu ketentraman dan ketertiban umum".

Berkaitan dengan hal tersebut, pengembangan tema dengan menggunakan kohesi leksikal yang menunjukkan keberpautan dan keterkaitan satu kata dengan kata yang lain mengindikasikan bahwa pemerintah sebagai pihak yang memiliki kuasa memiliki tendensi untuk mengarahkan persepsi masyarakat pada pernyataan bahwa FPI merupakan organisasi illegal yang mengganggu ketentraman dan ketertiban umum. Frasa "mengganggu ketentraman dan ketertiban umum", mengarahkan masyarakat pada anggapan bahwa pergerakan FPI mengarah pada pergerakan yang radikal, anarkis, dan intoleran sehingga menyebabkan pemerintah mengeluarkan larangan.

Berbeda dengan pengembangan tema-rema pada teks pertama, teks Maklumat Kapolri tentang Larangan Kegiatan FPI pada 1 Januari 2021 menggunakan konstruksi pengembangan dari Tema ke Tema yang menunjukkan bahwa terjadi penurunan tema dari klausa pertama menuju kepada tema klausa kedua dan seterusnya yang dicontohkan dalam kutipan berikut.

(19) Masyarakat (Tema) tidak terlibat secara langsung maupun tidak langsung dalam mendukung dan memfasilitasi kegiatan serta menggunakan simbol dan atribut FPI (Rema).

(20) Masyarakat (Tema) segera melaporkan kepada aparat yang berwenang apabila menemukan kegiatan, simbol dan atribut FPI (Rema).

(21) Masyarakat (Tema) mengedepankan Satpol PP dengan didukung sepenuhnya oleh TNI-Polri untuk melakukan penertiban di lokasi-lokasi yang terpasang spanduk/banner, atribut, pamflet, dan hal lainnya terkait FPI (Rema).

(22) Masyarakat (Tema) tidak mengakses, mengunggah, dan menyebarluaskan konten terkait FPI baik melalui website maupun media sosial (Rema).

Dalam kutipan (19), (20), (21), (22), diidentifikasi bahwa teks mengembangkan pola tema ke tema dengan mengulang-ulang kata masyarakat sebagai tema utama. Bloor dan Bloor (2004: 88-91) menyebut pengembangan pola ini dengan istilah the constant theme pattern. 


MIMESIS
Und. 2. No. 1, Januari 2021
Universitas
Ahmad Dahlan

Penggunaan kata masyarakat yang disebut berkali-kali mengindikasikan adanya pihak yang mencoba dibentuk persepsinya oleh pemerintah. Tujuan dari pemerintah dalam hal ini adalah untuk menarik persepsi masyarakat ke dalam ideologi bahwa FPI merupakan organisasi masyarakat yang menganut paham radikalisme, anarkisme dan intoleran, sehingga mampu merepresi eksistensi FPI di Indonesia.

Kemunculan wacana 7 larangan pemerintah terhadap FPI pada 30 Desember 2020 yang memberikan penekanan pada buruknya citra FPI serta Maklumat Kapolri tentang Larangan Kegiatan FPI pada 1 Januari 2021, menunjukkan adanya pembekuan kegiatan FPI melalui peraturan dan sanksi yang ditetapkan kepada masyarakat. Dalam waktu yang bersamaan, munculnya kedua wacana mengukuhkan adanya usaha pemerintah untuk mengakhiri kegiatan FPI di Indonesia dengan membentuk kuasa atas aparat negara, aparat penegak hukum serta masyarakat.

\section{Praktik Diskursif Wacana 7 Larangan Pemerintah terhadap FPI serta Maklumat Kapolri tentang Larangan Kegiatan FPI}

Analisis praktik diskursif wacana memusatkan perhatian pada bagaimana teks diproduksi dan dikonsumsi (Eriyanto, 2001: 317). Berkaitan dengan proses produksinya, wacana 7 larangan pemerintah terhadap FPI pada 30 Desember 2020 diterbitkan setelah disetujui dan ditandatangani bersama dalam bentuk Surat Keputusan Bersama (SKB) enam menteri dan lembaga (www.bbc.com). Enam menteri dan lembaga yang menandatangani SKB dengan Nomor 220/4780 Tahun 2020, Nomor M.HH/14.HH05.05 Tahun 2020, Nomor 690 Tahun 2020, Nomor 264 Tahun 2020, Nomor KB/3/XII Tahun 2020, dan Nomor 320 Tahun 2020 tentang Larangan Kegiatan Penggunaan Simbol dan Atribut serta Penghentian Kegiatan FPI adalah Mendagri Tito Karnavian, Menteri Hukum dan Hak Asasi Manusia Yasonna H. Loly, Menteri Komunikasi dan Informatika Johnny G. Plate, Jaksa Agung S. T. Burhanuddin, Kapolri Jenderal Polisi Idham Azis dan Kepala Badan Nasional Penanggulangan Terorisme (BNPT) Komjen Boy Rafli Amar. Adapun salah satu pertimbangan dalam keputusan adalah untuk menjaga eksistensi ideologi dan konsensus dasar bernegara yaitu Pancasila, UUD 1945, keutuhan NKRI, dan Bhineka Tunggal Ika. Sedangkan Maklumat Kapolri tentang Kepatuhan Terhadap Larangan Kegiatan, Penggunaan Simbol dan Atribut serta Penghentian Kegiatan FPI dikeluarkan oleh Kapolri Jenderal Polisi Idham Azis sebagai tindak lanjut dari SKB enam menteri dan lembaga.

Analisis terhadap konsumsi teks menunjukkan bahwa kedua wacana menyasar FPI sebagai pihak yang dikenakan otoritas atau aturan sehingga FPI tidak lagi memiliki legal standing. Sementara itu, masyarakat diposisikan sebagai pihak yang bertugas mengawasi serta menangkal adanya kegiatan-kegiatan FPI setelah FPI resmi dibubarkan berupa larangan terpengaruh dan terlibat dalam kegiatan FPI serta penggunaan simbol dan atribut FPI; larangan mengakses, mengunggah, dan menyebarluaskan konten terkait FPI baik melalui website maupun media sosial; serta perintah untuk melaporkan kepada aparat yang berwenang apabila terjadi pelanggaran.

\section{Praktik Sosial dan Intertekstual berkaitan dengan Relasi antara Pemerintah, FPI dan Masyarakat}

Dalam menganalisis praktik sosial dalam wacana, fungsi interpretasi mengambil peranan penting untuk menginterpretasikan teks itu sendiri serta bagaimana teks dikonsumsi dan diinterpretasikan oleh pendengar atau pembaca. Dalam hal ini, interpretasi dimaknai sebagai upaya penafsiran mengenai apa yang ada di dalam teks atau wacana dan apa yang ada di benak interpreter (Fairclough, 2013). Fairclough membagi prosedur interpretasi menjadi interpretasi terhadap teks dan interpretasi terhadap situasi kontekstualnya. Analisis yang 


MIMESIS
Und. 2. No. 1, Januari 2021
Universitas
Ahmad Dahlan

melibatkan fungsi interpretasi berada pada analisis di tingkat makro yang didasarkan pada pendapat bahwa konteks sosial yang ada di luar wacana sesungguhnya mempengaruhi bagaimana wacana dibentuk. Wacana yang dibentuk bukanlah ruang kosong yang steril melainkan sangat ditentukan oleh faktor-faktor di luar wacana itu sendiri.

Interpretasi konteks diklasifikasikan dalam dua domain (Fairclough, 2013), yaitu (1) konteks situasional yang ditelusuri dengan menganalisis tatanan-tatanan sosial yang bersifat institusional yang melingkupi peroduksi teks; (2) konteks intertekstual yang dianalisis melalui sejarah interaksional (interactional history) dari berbagai diskursus sehingga dapat dilihat diskursus mana yang berhubungan dengan diskursus dalam teks beserta asumsi-asumsi yang menentukan apakah diskursus diterima ataukah ditolak. Konteks situasional menandakan bahwa praktik sosial dalam wacana tidak hanya dibentuk dalam tataran struktural kalimat yang terdiri atas susunan pola subjek, predikat, objek, serta fungsi bahasa lainnya, melainkan pula terdapat aspek lain di balik wacana yang membentuk ideologi. Konteks situasional dibagi menjadi tiga tingkatan meliputi tingkat situasional, tingkat institutional dan tingkat sosial (Fairclough, 2013). Dengan demikian, interpretasi wacana pada teks wacana 7 larangan pemerintah terhadap FPI pada 30 Desember 2020 serta Maklumat Kapolri tentang Larangan Kegiatan FPI pada 1 Januari 2021 tidak dapat dilepaskan dari konteks, berhubungan dengan kepentingan berdasarkan ideologi tertentu.

Tingkat Situasional

Analisis di tingkat situasional berada pada anggapan bahwa setiap teks yang lahir, pada umumnya lahir pada sebuah kondisi atau suasanya yang khas (Fairclough, 2013). Berdasarkan analisis pada tataran deskriptif melalui teori Linguistik Sistemik Fungsional (LSF), pilihanpilihan kata dan klausa menggambarkan relasi kuasa antara pemerintah, Polri, FPI dan masyarakat. Adapun penafsiran wacana di tingkat situasional yang diperoleh melalui pisau bedah analisis metafungsi Linguistik Sistemik Fungsional (LSF) dijabarkan sebagai berikut.

(23) FPI (Token) adalah (Proses Relational-Identifying) organisasi yang tidak terdaftar sebagai organisasi kemasyarakatan sebagaimana diatur dalam peraturan undangundang (Value) sehingga secara de jure telah bubar sebagai organisasi kemasyarakatan (Circumstantial. Contingency. Condition).

(24) FPI (Actor) sebagai organisasi kemasyarakatan yang secara de jure telah bubar (Circumstantial. Contingency. Condition) masih terus melakukan (Proses MaterialDoing) kegiatan (Goal).

(25) Kegiatan FPI (Carrier) mengganggu (Relational-Atrributive) ketentraman dan ketertiban umum (Attribute).

(26) Kegiatan FPI (Actor) bertentangan (Proses Material-Happening) dengan hukum (Goal).

Dalam kutipan teks (23), (24), (25) dan (26), wacana yang hendak diproduksi oleh pemerintah adalah posisi FPI sebagai organisasi ilegal serta karakteristik FPI yang mengganggu ketentraman dan ketertiban umum serta menentang hukum. Konstruksi keempat klausa yang ada, mengakomodasi kepentingan pemerintah dalam usaha untuk membatasi ruang gerak FPI serta membentuk citra negatif masyarakat terhadap FPI. Dengan upaya ini, pemahaman pembaca atau pendengar secara masif digiring melalui pilihan-pilihan kata untuk mencapai tujuan bahwa FPI merupakan organisasi masyarakat ilegal yang intoleran terhadap pemerintah serta patut disalahkan atas munculnya berbagai aksi yang meresahkan masyarakat. Upaya ini bertujuan untuk mengaburkan asumsi masyarakat untuk melemparkan judgement kepada pemerintah, secara langsung mengarahkan masyarakat untuk memberikan pembelaan serta dukungan sepenuhnya kepada pemerintah. 


MIMESIS
Undiversitas
Ahmad Dahlan
VOL. No. 1, Januari 2021

Selama ini, FPI sebagai organisasi masyarakat dikenal tidak memiliki hubungan yang harmonis dengan pemerintah yang akhirnya memicu pembubaran FPI. Dikutip dari portal berita CNN Indonesia, FPI didirikan pada 17 Agustus 1998. Sejak awal didirikan, FPI kerap melontarkan sikap politik terhadap situasi negara. Sepanjang tahun 2020, setidaknya terdapat 5 catatan kontroversi berkaitan dengan FPI meliputi: (1) Kepulangan Habib Rizieq; (2) Kerumunan Pertamburan-Mega Mendung yang dianggap melanggar protokol Kesehatan di masa pandemi Covid-19; (3) Penembakan 6 Laskar FPI; (4) Penangkapan Habib Rizieq; yang berujung pada (5) Pembubaran FPI oleh pemerintah.

Tingkat Institusional

Tingkat institusional berkaitan dengan pengaruh institusi secara internal dan eksternal. Analisis di tingkat institusional melihat bagaimana persisnya sebuah pengaruh dari institusi organisasi pada praktik produksi wacana (Fairclough, 2013). Dalam wacana 7 larangan pemerintah terhadap FPI pada 30 Desember 2020 serta Maklumat Kapolri tentang Larangan Kegiatan FPI pada 1 Januari 2021, kekuatan istitusional pemerintah dan aparat menjadi kunci yang mempengaruhi dan membingkai keseluruhan wacana. Adapun penafsiran wacana di tingkat institusional yang diperoleh melalui pisau bedah analisis metafungsi Linguistik Sistemik Fungsional (LSF) dijabarkan sebagai berikut.

(27) Pemerintah (Sayer) melarang (Proses Verbal) dilakukannya kegiatan FPI serta penggunaan simbol dan atribut FPI (Verbiage) dalam wilayah hukum NKRI (Circumstantial. Location. Place).

(28) Aparat penegak hukum (Actor) akan menghentikan (Proses Material) seluruh kegiatan yang sedang dilaksanakan oleh FPI (Goal).

Dalam kedua klausa tersebut (kutipan 27 dan 28), wacana yang digulirkan oleh pemerintah mengarahkan pada pemberhentian dan pembubaran secara hukum kegiatan atau aktivitas FPI di Indonesia. Kegiatan organisasi FPI dihentikan setelah dianggap tidak memiliki kedudukan hukum sebagai organisasi masyarakat maupun organisasi biasa. Dikutip dari portal berita tempo.co., dalam surat keputusan bersama Mendagri, Menkum HAM, Menkominfo, Jaksa Agung, Kapolri, dan Kepala BNPT, terdapat enam hal yang menjadi pertimbangan pemerintah. Pertama, demi menjaga eksistensi ideologi dan konsensus dasar negara, yaitu Pancasila, UUD 1945, keutuhan NKRI, Bhinneka Tunggal Ika yang sesuai dengan UU Nomor 17 Tahun 2013 tentang organisasi masyarakat. Kedua, pemerintah menilai anggaran dasar FPI bertentangan dengan Pasal 2 Undang-Undang Ormas yaitu asas organisasi masyarakat tidak bertentangan dengan Pancasila dan UUD RI 1945. Ketiga, FPI belum memperpanjang surat keterangan terdaftar (SKT) sebagai ormas yang berlaku hingga 20 Juni 2019. FPI juga tidak memenuhi syarat untuk memperpanjang SKT. Sehingga secara de jure per tanggal 21 Juni 2019, FPI dianggap bubar. Keempat, kegiatan FPI dianggap telah bertentangan dengan pasal $5 \mathrm{G}$, pasal $6 \mathrm{~F}$, pasal $21 \mathrm{~B}$ dan $\mathrm{D}$, pasal 59 ayat 3 huruf $\mathrm{A}, \mathrm{C}$, dan $\mathrm{D}$; pasal 59 ayat 4 huruf C, serta pasal 82 UU Ormas. Kelima, anggota dan pengurus FPI terlibat dalam tindak pidana terorisme terkait praktik radikalisme dan anarkisme serta tindak pidana umum. Sebanyak 35 orang terlibat tindak pidana terorisme dan 20 diantaranya telah dijatuhi pidana. 206 orang anggota dan atau pengurus FPI terlibat berbagai tindak pidana umum, 100 diantaranya telah dijatuhi pidana. Keenam, anggota dan pengurus FPI kerap melakukan razia atau sweeping berbasis anarkisme. Kemunculan keenam alasan membentuk klasifikasi yang kemudian meletakkan FPI sebagai pihak yang menentang pemerintah serta menempatkan FPI dalam penggambaran yang negatif (negative other-representation).

Berkaitan dengan relasi antara FPI dan pemerintah di tingkat institusional, wacana yang dibentuk pemerintah membentuk wacana strategis dimana hubungan antar dua pihak bersifat 


MIMESIS
Und. 2. No. 1, Januari 2021
Universitas
Ahmad Dahlan

asimetris (tidak sejajar) dalam hak dan akses terhadap distribusi kekuasaan dan status sosial. Putusan pemerintah serta alasan berlandaskan hukum digunakan sebagai upaya untuk melanggengkan legitimasi pemerintah untuk membubarkan FPI.

Tingkat Sosial

Tingkat sosial berkaitan dengan situasi yang lebih makro, seperti sistem politik, sistem ekonomi dan sistem budaya masyarakat secara keseluruhan (Fairclough, 2013). Berdasarkan analisis terhadap wacana 7 larangan pemerintah terhadap FPI pada 30 Desember 2020 serta Maklumat Kapolri tentang Larangan Kegiatan FPI pada 1 Januari 2021, masyarakat ditahan dalam aturan yang dikehendaki dan dinilai peran serta statusnya ke dalam dikotomi bawahanatasan (inferior-superior). Hal ini diupayakan melalui sistem strategi sosial yang melibatkan aspek kekuasaan, aturan, subordinasi, sebagai bagian integral dari sistem pengontrolan terhadap masyarakat. Strategi sosial dalam hal ini diwujudkan dalam wacana 7 larangan pemerintah terhadap FPI pada 30 Desember 2020 serta Maklumat Kapolri tentang Larangan Kegiatan FPI pada 1 Januari 2021 yang mengikat masyarakat secara penuh dalam usaha menghentikan pergerakan FPI menyikapi budaya masyarakat Indonesia yang sangat mudah terjerumus serta menyebarluaskan informasi yang belum tentu kebenarannya. Berkaitan dengan hal ini, pemerintah secara sadar membendung serta membentengi potensi membesarnya simpati publik yang mampu mendorong pendirian FPI versi baru sebagai organisasi yang lebih besar. Adapun upaya legitimasi pemerintah terhadap masyarakat dijabarkan dalam contoh kutipan berikut.

(29) Masyarakat (Actor) tidak terlibat (Proses Material.Doing) secara langsung maupun tidak langsung (Circumstantial. Manner. Means) dalam mendukung dan memfasilitasi kegiatan serta menggunakan simbol dan atribut FPI (Goal).

(30) Masyarakat (Senser) agar tidak terpengaruh (Proses Mental.Desiderative) dan terlibat (Proses Material.Doing) dalam kegiatan, penggunaan simbol dan atribut FPI (Phenomenon/Goal).

(31) Masyarakat (Sayer) melaporkan (Proses Verbal) kepada aparat penegak hukum (Receiver) setiap kegiatan, penggunaan simbol dan atribut FPI (Verbiage).

(32) Masyarakat (Actor) tidak mengakses, mengunggah, dan menyebarluaskan (Proses Material. Doing) konten terkait FPI (Goal) baik melalui website maupun media sosial (Circumstantial. Manner. Means).

Konstruksi Ideologi Pemerintah terhadap FPI dan Masyarakat dalam Wacana 7 Larangan Pemerintah terhadap FPI serta Maklumat Kapolri tentang Larangan Kegiatan FPI

Pendekatan analisis wacana secara serius mengkaji hubungan antara bahasa dengan ideologi yang dikonstruksi oleh si pembuat wacana dalam hubungan yang bersifat dialektik (Wodak dan Meyer, 2008). Selanjutnya, Fairclough (2002) menjelaskan bahwa ideologi merupakan makna yang melayani kekuasaan. Ideologi merekonstruksi makna yang memberikan kontribusi bagi produksi, reproduksi dan transformasi hubungan-hubungan dominasi.

Konstruksi ideologi dalam wacana 7 Larangan Pemerintah terhadap FPI pada 30 Desember 2020 serta Maklumat Kapolri tentang Larangan Kegiatan FPI pada 1 Januari 2021 tercermin dalam bentuk upaya pemerintah melegitimasi keadaan dengan menunjukkan adanya ketidaksetaraan kuasa yang hendak dilanggengkan dan dipertahankan melalui aturan yang ada. Dalam hal ini, pemerintah diindikasikan hendak memelihara relasi kuasa dengan merepresi pihak yang hendak menentang kekuasaan negara. Hal ini dilanggengkan dengan menyebut FPI sebagai organisasi yang melakukan praktik radikalisme, anarkisme dan intoleran melalui 


MIMESIS
Universitas
Ahmad Dahlan

pilihan-pilihan kata seperti FPI tidak terdaftar sebagai organisasi kemasyarakatan, kegiatan FPI mengganggu ketentraman dan ketertiban umum, serta kegiatan FPI yang bertentangan dengan hukum. Konstruksi ideologi yang dilanggengkan pemerintah dan aparat semakin menegaskan adanya upaya dalam menghegemoni ideologi yang dominan.

Dengan cara yang telah disebutkan di atas, pemerintah membingkai masyarakat pada ideologi bahwa pihak-pihak yang berusaha menentang pemerintah dengan kekerasan adalah pihak yang radikal, anarkis dan intoleran. Dengan cara ini, relasi kuasa yang tidak setara menjadi kabur karena persepsi masyarakat terhadap pemerintah dialihkan fokusnya ke arah pihak yang memicu konflik, memposisikan pemerintah sebagai pihak yang direpresi dan dilanggar otoritasnya

\section{KESIMPULAN}

Merujuk pada hasil dan pembahasan yang telah dipaparkan, maka dapat ditarik kesimpulan bahwa: Ditinjau melalui analisis deskripsi menggunakan pisau bedah SFL, (a) Secara umum, terdapat perbedaan mendasar pada kedua teks yang diajukan pemerintah dan Kapolri terkait dengan larangan untuk FPI jika dipandang melalui struktur transitivitas. Teks 7 larangan pemerintah terhadap FPI pada 30 Desember 2020 memiliki otoritas yang penuh dengan memberikan perintah kepada seluruh aspek yang terkait dan berpotensi memiliki keterkaitan. Sedangkan, Maklumat Kapolri tentang Larangan Kegiatan FPI pada 1 Januari 2021, Kapolri berada di bawah otoritas dan kuasa pemerintah; (a) Berdasarkan analisis yang telah dilakukan terhadap Maklumat Kapolri tentang Larangan Kegiatan FPI pada 1 Januari 2021, elemen sirkumstansi muncul dalam bentuk cara dan tujuan guna memperjelas isi maklumat. Sedangkan pada teks 7 larangan pemerintah terhadap FPI pada 30 Desember 2020 elemen sirkumstansi didominasi dalam bentuk waktu dan kondisi. Hal ini berkaitan dengan relevansi larangan dihubungkan dengan konteks permasalahan yang dihadapi; (b) Konstruksi teks dengan dominasi modus deklaratif merupakan cara pemerintah untuk membingkai masyarakat dalam persepsi-persepsi pemerintah, sedangkan modus imperative merupakan usaha pemerintah untuk menunjukkan otoritas; (c) Analisis terhadap pengembangan tema dan rema menunjukkan bahwa kemunculan wacana 7 larangan pemerintah terhadap FPI pada 30 Desember 2020 yang memberikan penekanan pada buruknya citra FPI serta Maklumat Kapolri tentang Larangan Kegiatan FPI pada 1 Januari 2021, menunjukkan adanya pembekuan kegiatan FPI melalui peraturan dan sanksi yang ditetapkan kepada masyarakat. Dalam waktu yang bersamaan, munculnya keedua wacana mengukuhkan adanya usaha pemerintah untuk mengakhiri kegiatan FPI di Indonesia dengan membentuk kuasa atas aparat negara, aparat penegak hukum serta masyarakat.

Ditinjau melalui analisis praktik diskursif wacana, analisis terhadap konsumsi teks menunjukkan bahwa kedua wacana menyasar FPI sebagai pihak yang dikenakan otoritas atau aturan sehingga FPI tidak lagi memiliki legal standing. Sementara itu, masyarakat diposisikan sebagai pihak yang bertugas mengawasi serta menangkal adanya kegiatan-kegiatan FPI setelah FPI resmi dibubarkan.

Ditinjau melalui analisis praktik sosial dan intertekstualitas, pada tingkat situasional, konstruksi serta pilihan kata yang ada, mengakomodasi kepentingan pemerintah dalam usaha untuk membatasi ruang gerak FPI serta membentuk citra negatif masyarakat terhadap FPI. Pada 


MIMESIS
Und. 2. No. 1, Januari 2021
Universitas
Ahmad Dahlan

tingkat institusional, kekuatan istitusional pemerintah dan aparat menjadi kunci yang mempengaruhi dan membingkai keseluruhan wacana. Pada tingkat sosial, masyarakat ditahan dalam aturan yang dikehendaki dan dinilai peran serta statusnya ke dalam dikotomi bawahanatasan (inferior-superior). Hal ini diupayakan melalui sistem strategi sosial yang melibatkan aspek kekuasaan, aturan, subordinasi, sebagai bagian integral dari sistem pengontrolan terhadap masyarakat.

Konstruksi ideologi dalam wacana 7 larangan pemerintah terhadap FPI pada 30 Desember 2020 serta Maklumat Kapolri tentang Larangan Kegiatan FPI pada 1 Januari 2021 tercermin dalam bentuk upaya pemerintah melakukan legitimasi dengan menunjukkan adanya ketidaksetaraan kuasa yang hendak dilanggengkan dan dipertahankan melalui aturan yang ada serta melalui pilihan-pilihan kata yang direpresentasikan dalam kedua wacana dengan menonjolkan aspek lingual yang secara implisit menegaskan bahwa FPI mengarah pada praktik radikalisme, anarkisme dan intoleran.

\section{DAFTAR PUSTAKA}

Halliday, M. (2004). An Introduction to Functional Grammar (4 ed.). New York: Oxford University Press.

Halliday, M., \& Matthiessen, M. (2014). Halliday's Introduction to Functional Grammar (4 ed.). New York: Hodder Arnold.

Fairclough, N. (1995). Critical Discourse Analysis: The Critical Study of Language. London: Longman Group Limited.

Dijk, T. V. (2004). Critical Discourse Analysis. In D. Schriffin, D. Tannen, \& H. E. Hamilton, The Book of Discourse Analysis (pp. 352-371). Oxford: Blackwell.

Silaswati, D. (2019). Analisis Wacana Kritis Dalam Pengkajian Wacana. METAMORFOSIS: Jurnal Bahasa, Sastra Indonesia dan Pengajarannya, 12(1), 1-10.

Paltridge, B. (2012). Discourse Analysis: An Introduction. London and New York: Bloomsburry Academic.

Jorgensen, M., \& Phillips, L. J. (2002). Discourse Analysis as Theory and Method. London: Sage Publications.

Rumata, V. M., \& Elfrida, S. V. (2019). Ideologi dan Kekuasaan Pemerintah di Balik Wacana Pembangunan Tol Laut - Analisis Wacana Kritis Terhadap Materi Siaran DBU LPP RRI Sorong, 20 Oktober 2017. Jurnal Penelitian Komunikasi dan Opini Publik, 23(2), 90-103.

Anggito, A., \& Setiawan, J. (2018). Metodologi Penelitian Kualitatif. Jawa Barat: CV. Jejak.

Suswandi, I. (2020). Representasi Kelugasan Beranda Laman www.covid-19.go.id: Tinjauan Analisis Wacana Kritis. Mimesis, 1(2), 21-43.

Wiratno, T. (2018). Pengantar Ringkas Linguistik Sistemik Fungsional. Yogyakarta: Pustaka Pelajar.

CNNIndonesia. (2021). Isi Maklumat Kapolri tentang Larang Simbol FPI di Masyarakat. Retrieved January 6, 6rom https://www.cnnindonesia.com/nasional/20210101110207-12-588432/isi-maklumatkapolri-tentang-larang-simbol-fpi-di-masyarakat.

BBCNews Indonesia. (2021). Pemerintah larang kegiatan FPI, polisi larang masyarakat unggah dan sebarkan konten terkait FPI. Retrieved Januari 5, 2021, from https://www.bbc.com/indonesia/indonesia-55481350. 


MIMESIS
Universitas
Ahmad Dahlan
VOL. 2. No. 1, Januari 2021

Chaer, A. (1994). Linguistik Umum. Jakarta: Rineka Cipta.

Alwi, H. (1992). Modalitas dalam Bahasa Indonesia. Yogyakarta: Kanisius.

Eggins, S. (2004). An Introduction to Systemic Functional Linguistics (2 ed.). New York: Continuum.

Eriyanto. (2001). Analisis Wacana: Pengantar Analisis Teks Media. Yogyakarta: LKiS.

Martin, J., Matthiessen, C., \& Painter, C. (1997). Working with Functional Grammar. London: Arnold.

Saragih, A. (2007). Fungsi Tekstual dalam Wacana: Panduan Menulis Rema dan Tema. Medan: Balai Bahasa.

Bloor, T., \& Bloor, M. (2004). The Functional Analysis of English: A Hallidayan Approach. London: Arnold.

Fairclough, N. (2013). Critical Discourse Analysis: The Critical Study of Language (2 ed.). London: Routledge.

Tempo.co. (2021). UU Ormas Dasar Pembubaran FPI Bermasalah karena Hilangkan Mekanisme Peradilan. Retrieved January 6, 2021, from https://nasional.tempo.co/read/1418960/uu-ormas-dasar-pembubaran-fpi-bermasalahkarena-hilangkan-mekanisme-peradilan/full\&view $=\mathrm{ok}$.

Wodak, R., \& Meyer, M. (2008). Methods of Critical Discourse Analysis (2 ed.). London and Canada: Sage Publishing.

Fairclough, N. (2002). The dialectics of discourse. TEXTUS, 14(2), 3-10. Retrieved from http://www.ling.lancs

Halliday, M., \& Matthiessen, M. (2004). Halliday's Introduction to Functional Grammar (3 ed.). UK: Hodder Education.

KompasTV. (2020). FPI Dilarang, Ini 7 Poin Larangan dari Pemerintah Indonesia. Retrieved December 26, 2020, from https://www.kompas.tv/article/134178/fpi-dilarang-ini-7poin-larangan-dari-pemerintah-indonesia.

Wiratno, T., \& Santoso, R. (2011). Pengantar Linguistik Umum. Tangerang Selatan: Universitas Terbuka. 